\title{
Everything you wanted to know about regime shifts in the marine environment and have not dared to ask, yet
}

\author{
Antonio Pusceddu, ${ }^{1}$ Silvia Bianchelli ${ }^{2}$ \\ ${ }^{1}$ Dipartimento di Scienze della Vita e dell'Ambiente, Università degli Studi di Cagliari, Via Fiorelli, 1, 09126 Cagliari, Italy; \\ ${ }^{2}$ Dipartimento di Scienze della Vita e dell'Ambiente, Università Politecnica delle Marche, Via Brecce Bianche, 60131 Ancona, Italy
}

To usher in a shift, the new editorial shape and the new Publisher of Advances in Limnology and Oceanography, we could not have hoped better than providing our members and authors a review of a special issue of Philosophical Transactions of the Royal Society B devoted to the Regime Shifts in the marine environment.

When, in the mid-80s of the last century, the scientific community has begun to alert the world's governments about the imminence and the possible consequences of global change on the worldwide oceans, the underwater landscape was indeed not too different from what, in the late $50 \mathrm{~s}$, the first and pioneering underwater filming had shown. Today, little more than 30 years after those first aware signs of alarm, we are faced with the blatant evidence of a change of the underwater seascape (Boström et al., 2011) that not only hit the coastal seas that we can all look through the glass of a mask, but has now begun to affect manifestly even the deep ocean (Danovaro et al., 2013). We also know that such changes were not always smooth, but also sudden, tangible, measurable and dramatic in their manifestation (Scheffer and Carpenter, 2003). These sudden changes may affect populations, communities or whole ecosystems and are known as regime shifts (Scheffer, 2009).

The January 2015 special issue of Philosophical Transactions of the Royal Society B entitled Marine regime shifts around the globe: theory, drivers and impacts edited by Alessandra Conversi, Christian Möllmann, Carl Folke and Martin Edwards, includes 14 articles introduced by a foreword perspective (Möllman et al., 2015) and a closing executive summary with holistic ambitions (Conversi et al., 2015) that collects the summa of knowledge, uncertainties and gaps accumulated to date about the understanding of regime shifts in the marine environment, their causes and the harmful consequences they can have on marine ecosystems and related services. Overall, the special issue is cleverly organized according to a logical flow that highlights, first of all, the theoretical aspects and the emerging issues of the more recent research on marine regime shifts, identifies their main drivers, and provides a list of tools to adaptively manage ecosystems affected by regime shifts; furthermore, it also provides a critical revision of the 'regime shift' concept, as well as insights and ideas for future directions of investigation.

Prestigious worldwide-recognized marine ecologists, including the most known experts of marine regime shifts, signed critical reviews dedicated to indicators of resilience (Dakos et al., 2015), mechanisms underlying the formation of alternative stable states (Gårdmark et al. 2015), the theoretical bases for the prediction of regime shifts led by climate (Beaugrand, 2015), the different types of regime shifts and their causes (Jouffray et al., 2015), the resilience of coral reefs to global warming (Bozec et al., 2015), the role of overgrazing by sea urchins (Ling et al., 2015) and trophic cascades (Pershing et al., 2015), the planetary value of regime shifts in the ocean (Beaugrand et al., 2015), the issues of scale of regime shifts drivers (Fisher et al., 2015) and their impacts on ecosystem services (Rocha et al., 2015).

The following four articles are devoted to the management of regime shifts and, in particular, to the opportunities of an ecosystem-based management approach (Levin and Möllmann, 2015), to the major issues associated with fisheries management (King et al., 2015), to the identification of appropriate thresholds of management (Kelly et al., 2015), to the issues related to the fishing effort by the Soviet Union (Österblom and Folke, 2015). The final chapter, in an attempt to provide a holistic approach, sums up the known and unknown about regime shifts, their triggering mechanisms, their development, and their ecological consequences, ultimately proposing the future research challenges for the coming years.

Not to forget that the special issue is dedicated to Frédéric Ibañez esteemed numerical ecologist of the Laboratory of Oceanography of Villefranche-sur-Mer.

In just over 150 pages this special issue of Philosophical Transactions B edited by Conversi et al. represents a seminal reference not only for those who will decide to go into the study and understanding of regime shifts in the marine environment, but also a very useful compendium for students in advanced $\mathrm{PhD}$ courses in disci- 
plines such as biological oceanography or marine ecology. Ultimately, a must read for any marine ecologist.

\section{References}

Beaugrand G, 2015. Theoretical basis for predicting climate-induced abrupt shifts in the oceans. Phil. Trans. R. Soc. B 370: 20130264.

Beaugrand G, Conversi A, Chiba S, Edwards M, Fonda-Umani S, Greene C, Mantua N, Otto SA, Reid PC, Stachura MM, Stemmann L, Sugisaki H, 2015. Synchronous marine pelagic regime shifts in the Northern Hemisphere. Phil. Trans. R. Soc. B 370:20130272.

Boström C, Pittman SJ, Simenstad C, Kneib RT, 2011. Seascape ecology of coastal biogenic habitats: advances, gaps, and challenges. Mar. Ecol. Progr. Ser. 427:191-217.

Bozec Y-M, Mumby PJ, 2015. Synergistic impacts of global warming on the resilience of coral reefs. Phil. Trans. R. Soc. B 370:20130267.

Conversi A, Dakos V, Gårdmark A, Ling S, Folke C, Mumby PJ, Greene C, Edwards M, Blenckner T, Casini M, Pershing A, Möllmann A, 2015. A holistic view of marine regime shifts. Phil. Trans. R. Soc. B 370:20130279.

Dakos V, Carpenter SR, van Nes EH, Scheffer M, 2015. Resilience indicators: prospects and limitations for early warnings of regime shifts. Phil. Trans. R. Soc. B 370:20130263.

Danovaro R, Snelgrove P, Tyler P, 2013. Challenging the paradigms of deep-sea ecology. Trends Ecol. Evol. 29:465-475.

Fisher JAD, Casini M, Frank KT, Möllmann C, Leggett WC, Daskalov G, 2015. The importance of within-system spatial variation in drivers of marine ecosystem regime shifts. Phil. Trans. R. Soc. B 2015 370:20130271.

Gårdmark A, Casini M, Huss M, van Leeuwen A, Hjelm J, Persson L, de Roos AM, 2015. Regime shifts in exploited marine food webs: detecting mechanisms underlying alternative stable states using size-structured community dynamics theory. Phil. Trans. R. Soc. B 370:20130262.
Jouffray J-B, Nyström M, Norström AV, Williams ID, Wedding LM, Kittinger JN, Williams GJ, 2015. Identifying multiple coral reef regimes and their drivers across the Hawaiian archipelago. Phil. Trans. R. Soc. B 370:20130268.

Kelly RP, Erickson AL, Mease LA, Battista W, Kittinger JN, Fujita R, 2015. Embracing thresholds for better environmental management. Phil. Trans. R. Soc. B 370:20130276.

King JR, McFarlane GA, Punt AE, 2015. Shifts in fisheries management: adapting to regime shifts. Phil. Trans. R. Soc. B 370:20130277.

Levin PS, Möllmann C, 2015. Marine ecosystem regime shifts: challenges and opportunities for ecosystem-based management. Phil. Trans. R. Soc. B 370:20130275.

Ling SD, Scheibling RE, Rassweiler A, Johnson CR, Shears N, Connell SD, Salomon AK, Norderhaug KM, Pérez-Matus A, Hernández JC, Clemente S, Blamey LK, Hereu B, Ballesteros E, Sala E, Garrabou J, Cebrian E, Zabala M, Fujita D, Johnson LE, 2015. Global regime shift dynamics of catastrophic sea urchin overgrazing. Phil. Trans. R. Soc. B 370: 20130269.

Möllmann C, Folke C, Edwards M, Conversi A, 2015. Introduction: Marine regime shifts around the globe: theory, drivers and impacts. Phil. Trans. R. Soc. B 2015 370:20130260.

Österblom H, Folke C, 2015. Globalization, marine regime shifts and the Soviet Union. Phil. Trans. R. Soc. B 2015 370: 20130278.

Pershing AJ, Mills KE, Record NR, Stamieszkin K, Wurtzell KV, Byron CJ, Fitzpatrick D, Golet WJ, Koob E, 2015. Evaluating trophic cascades as drivers of regime shifts in different ocean ecosystems. Phil. Trans. R. Soc. B 370:20130265.

Rocha J, Yletyinen J, Biggs R, Blenckner T, Peterson G, 2015. Marine regime shifts: drivers and impacts on ecosystems services. Phil. Trans. R. Soc. B 370:20130273.

Scheffer M, 2009. Critical transitions in nature and society. Princeton University Press, Princeton, NJ, USA: 400 pp.

Scheffer M, Carpenter SR, 2003. Catastrophic regime shifts in ecosystems: linking theory to observation. Trends Ecol. Evol. 18:648-656. 